\title{
Notes on the Genus Picturaphis and Related Genera with a New Species of Picturaphis from Puerto Rico (Aphididae: Homoptera) ${ }^{1}$
}

\author{
Clyde F. Smith ${ }^{2}$ \\ INTRODUCTION
}

Blanchard $(1)^{3}$ erected the genus Picturaphis for the new species vignaphila. He noted that Picturaphis showed close relationship with Idiopterus Davis (8) and Pentalonia Cocquerel (2). Picturaphis is also closely related to Microparsus Patch (5) and Megouroparsus Smith and Heie (6) in that the hind wings show a reduction in size and usually the loss of the cubitus. Also, some or all of the veins of the fore wings of all five genera are broadly bordered with fuscous and the media may have one or two branches.

The following abbreviations are used in the keys and descriptions:

a.s. - antennal segments

$\mathrm{R} I V+\mathrm{V} \rightarrow$ rostral segments IV + V

p.t.-processus terminalis

t.ch.-tarsomere I chaetotaxy

KEY TO APTERA OF ABOVE GENERA

$1 \quad$ Head denticulate . . . . . . . . . . . . . . . . . . . .

Head smooth. ..........................

2(1) Disual $2 / 5$ or more of siphunculi dark, base pale or dark.......3 Distal $1 / 2$ of siphunculi pale, base dark. Abdominal setae on small tubercles (figs. $1 \mathrm{~B}, 3 \mathrm{~A}$ ) . . . . . . . Idiopterus

3(2) A.s. III without sensoria (figs. 1A, 2C) . ......... Pentalonia A.s. III with 1 or 2 sensoria (figs. 1C, 4).......... Picturaphis

4(1) Siphunculi subcylindrical (figs. 1D, 2B) ........... Microparsus Siphunculi swollen (figs. 1E, 2A) .............Megouroparsus

KEY TO APTERA OF Picturaphis

1 Siphunculi $1.7-2.0$ times length of cauda. . . . . . . . . . . . Siphunculi 1.1-1.5 times length of cauda (figs. 1C, 4A) .Picturaphis brasiliensis (Mloreira)

1 Joint paper of the North Carolina State University, Agricultural Experiment Station. Journal Paper No. 3123, Raleigh, N.C. and the Agricultural Experiment Station, Mayagüez Campus, University of Puerto Rico, Río Piedras, P.R.

${ }^{2}$ IResearch Professor of Entomology, North Carolina State University at Raleigh, N.C.

${ }^{3}$ Italic unmbers in parentheses refer to Literature Cited, p. 688. 

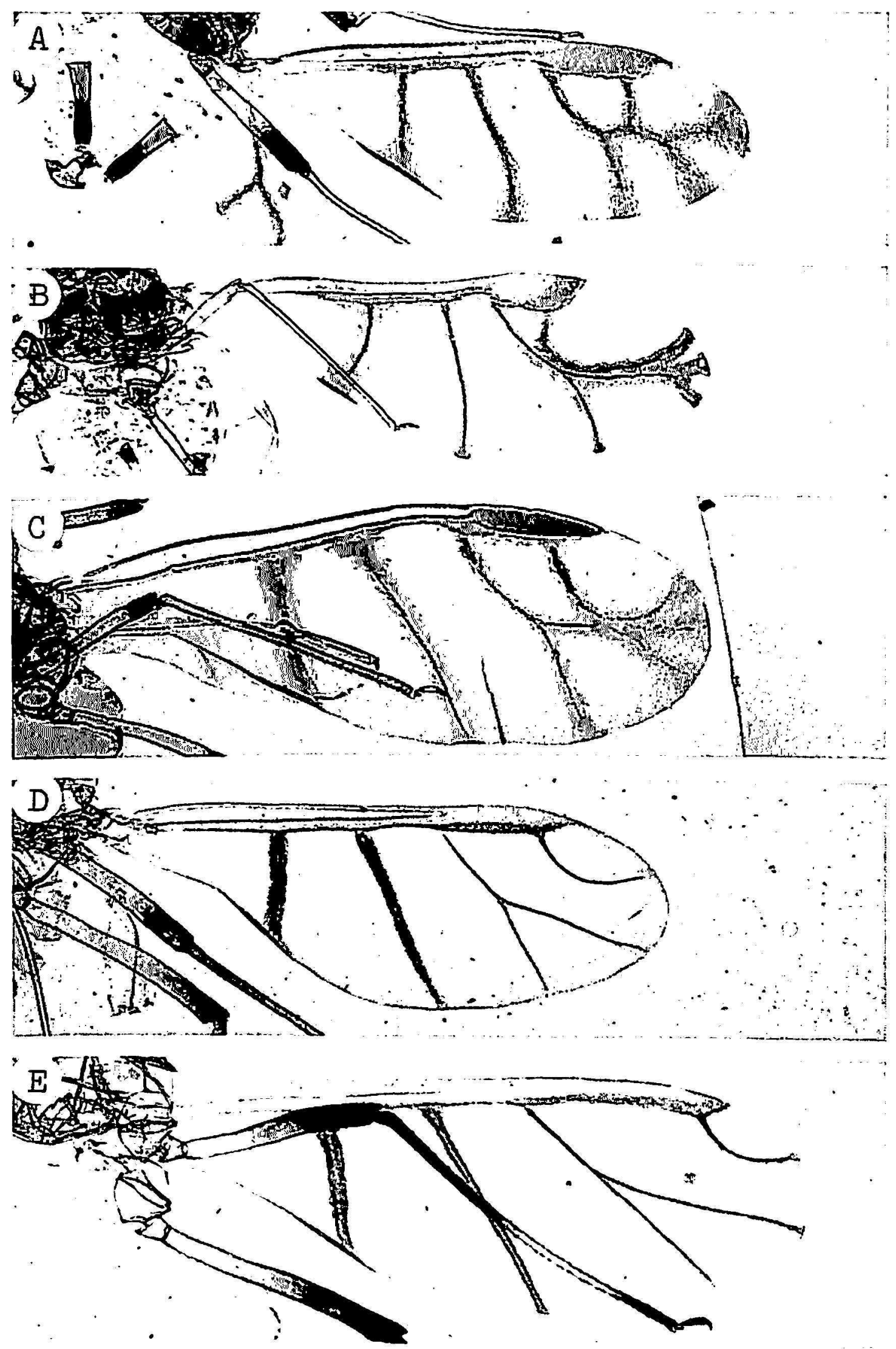

Fua. 1.-A, Penlalonia nigronervosa Coquerel $30 \times$ Coll. 60-146(H) on Musa sapientum, Villalba-Doña Juána Rd., P.R., April 26, 1960. B. Idioplerus nephrolepidis Davis $30 \mathrm{X}$ Coll. (i2-2-(W) on Saxifraga michanxii, in greenhouse, Raleigh, N.C., 130-62. C, Picluraphis brasiliensis $30 \times$ Coll. (57-190 on Phaseolus lunatus, Flo.ida, P.IR. 4-11-67. D, Microparsus olive $i$ Smith and Tuatay $30 \times$ Coll. 69-59. on Meibomia supina, lijo Piedras, P.R., Mareh 23, 1959. E, Megouroparsus tephrosiae (Smith) $30 \mathrm{X}$ Coll. 59-169(2) on Tephrosia, Norman, N.C., May 22, 1959. 
2(1) Aptera dark brown to blackish; basal 1/3-2/3 of siphunculi pale; meta-tarsomere I with middle seta $2 / 5-3 / 5$ length of other two setae; body 1.9-2.44 (South American species, not collected in Puerto Rico) (fig. 4C) ........P. vignaphila Blanchard Aptera reddish-brown, shiny; basal 1/5-2/5 of siphunculi pale; metatarsomere I with middle seta 0.6-1.0 length of other two setae; body 1.3-1.9 (fig. 4B)........... p. puertoricensis n. sp.
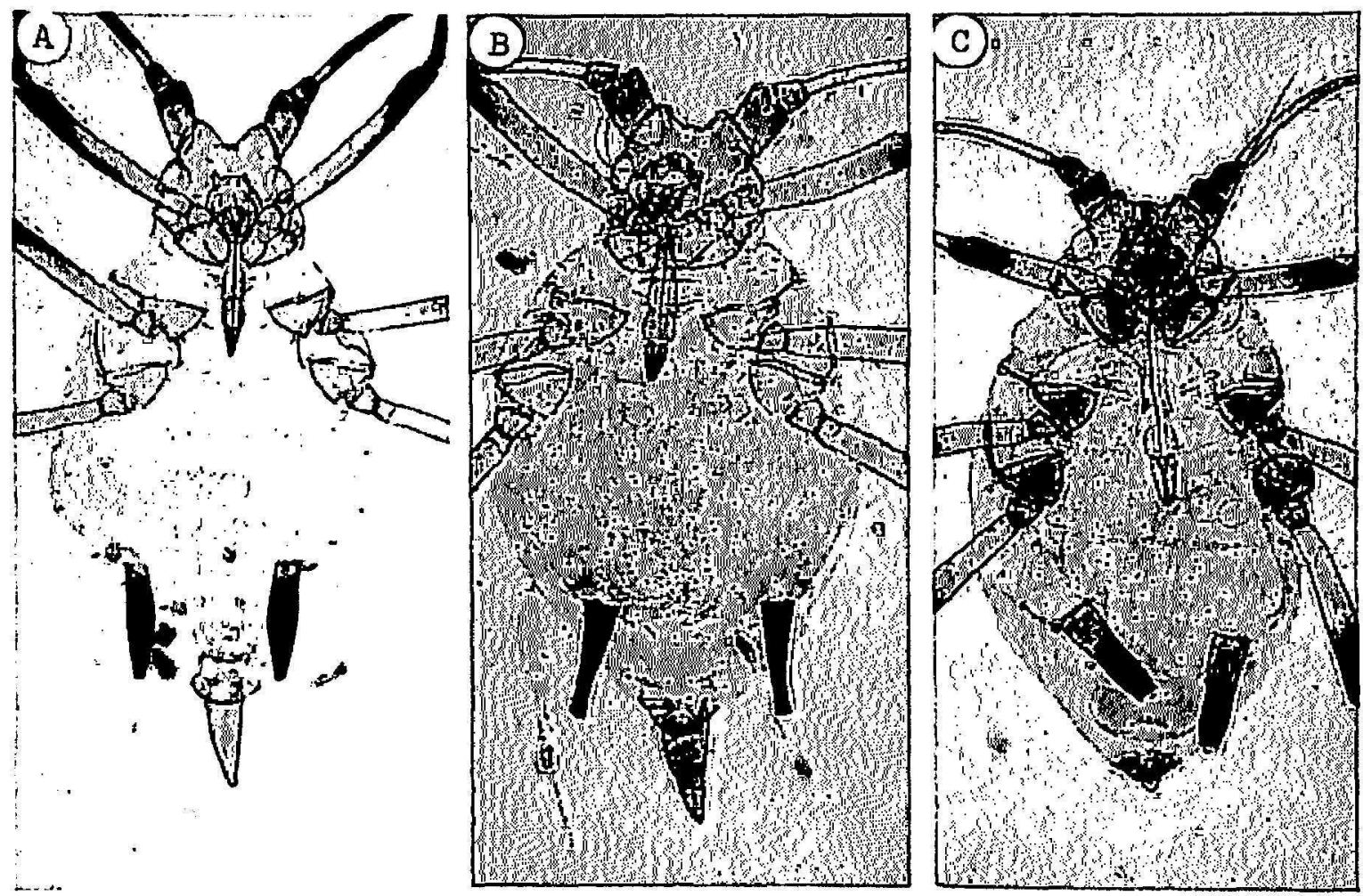

Fig. 2.-A, Megouroparsus lephrosiae (Smith) $43 \times$ Coll. 59-169 on Tephrosiae, Norman, N.C., May 22, 1959. B, Microparsus variabilis Patch 43 X Coll. 59-933(2) on Desmodium canalensis, Veazie, Maine, Aug. 15, 1959. C, Penlalonia nigronervosa Coquerel 43 X Coll. 60-146(H) on Musa sapienlum, Villalba-1)uña Juána Rd., P.R., April 26, 1960.

\section{Picturaphis brasiliensis (Moreira 1925:26)}

Moreira (4) described brasiliensis in the genus Idiopterus. Smith, Martorell, and Pérez (7) placed brasiliensis in the genus Picturaphis and gave a description of the aptera and alate vivipara.

The principal distinguishing characters of $P$. brasiliensis aptera are: Color of living specimens dark brown to nearly black; siphunculi 1.1-1.i) times length of cauda; basal 1/3-1/2 of siphunculi pale; meta-tarsomere I with middle seta $1 / 2-3,4$ length of other two setae.

$P$. brasiliensis has been collected in Puerto Rico on Dolichos lablab and Phaseolus lunatus.

${ }^{4}$ All measurements are in millimeters. 


\section{Picturaphis puertoricensis n. sp.}

I have been unable to locate type slides of Picturaphis brasiliensis (Moreira) and Picturaphis vignaphila Blanchard. However, $P$. puertoricensis n. sp. differs from sepcimens in the U.S. National Museum and the British

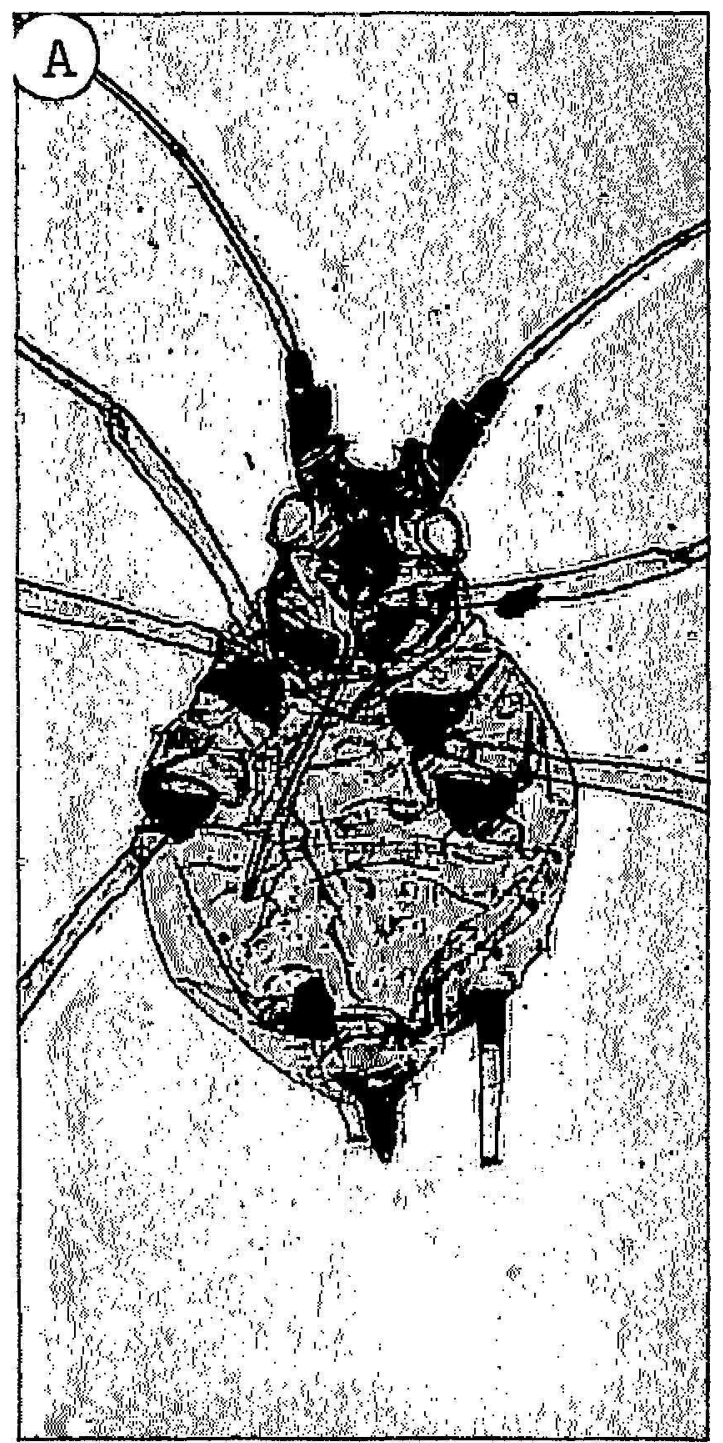

Fıg. 3.-A, Llioplerus nephrolepidis 1)avis $43 \times$ Coll. (i1-234 on Fern, Blue Ridge Parkway, N. C., Sept. 10, 1961.

Museum which are believed to be representative of $P$. brasilensis and $\mathrm{I}$. signaphila, as indicated in the key to the aptera.

Apterous vivipara.

Living specimens reddish-brown, shiny. The nymphs show the same color characteristics as the adults. Head, all antennal segments, joint between femur and tibia, distal $1 / 10$ of tibia, all tarsi, distal 0.6-0.S of si-hunculi, cauda, genital plate, and post siphuncular sclerites of cleared specimens dark. Remaining portions of body and alppendiages pale to slightly dusky. 
Head denticulate. Antennal segment III with one sensorium. Rostrum ittaining 1st abdominal segment. $R$ IV $+V$ with two accessory setae. T. ch. 3-3-3, middle seta stouter and 0.6-1 times length of other two setae. Bases of small tubercles on sides of abdomen dark. Siphunculi reticulate.

Length of body $1.30(1.30-1.55) .{ }^{5}$ Width of head, (0.42-0.48). Setile on vertex of head and on antennate short and blunt 0.006 . A.s. III, 0.43 (0.43$0.58) \mathrm{IV}, 0.37(0.37-0.46) \mathrm{V}, 0.3 .3(0.32-0.40) \mathrm{VI}, 0.12,(0.12-0.13)+0.67$

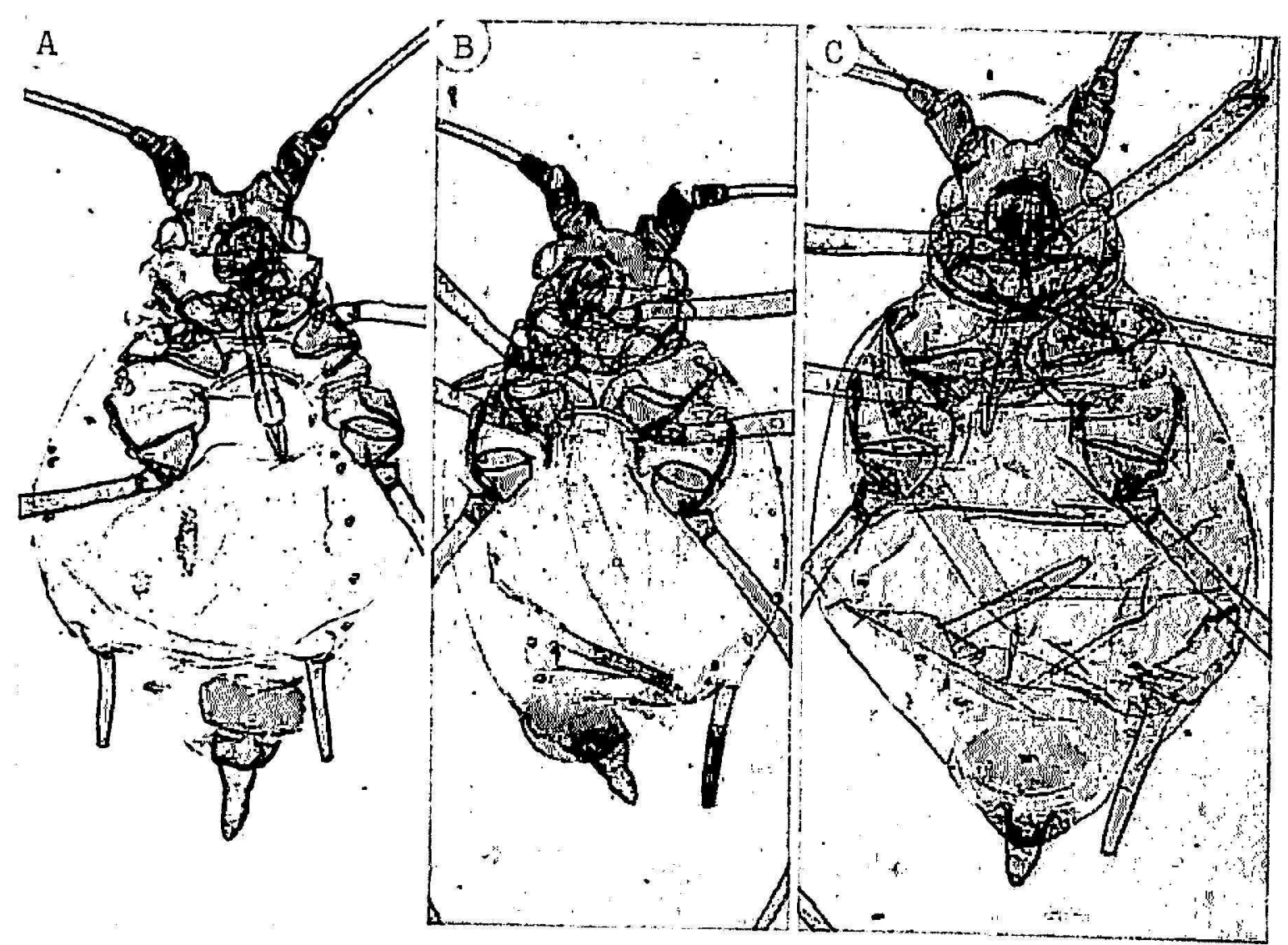

Fig. 4. -A, Picluraphis brasiliensis (Moreina) t3 X Coll. (99-32(3) on Phaseolus: trichocarpus, Florida, P.R., Mareh 10, 1969. B, Picluraphis puerloricensis n. sp. $43 \times$ Coll. 69-65(18) on Phaseolus adenanthus, Wal Yunque, P.1R., March 13, 1969. C, Picturaphis vignaphila Blanchard $43 \times$ ISNM No. 59 18589 on Phaseolus vulgaris, Medellin, Colombia, August 10, 1959.

(0.61-0.74). R IV + V, $0.10(0.10-0.11)$. Hind tibia $1.17(1.17-1.37)$. Hind tarsomere II, $0.10(0.09-0.11)$. Siphunculi $0.32(0.32-0.39)$. Cauda 0.17 $(0.16-0.21)$ and bearing seren setale, one on the dorsum and three on each side.

Principal diagnostic chatracters: Living specimens shiny, reddish-brown; siphunculi 1.7-2.0 times length of caudia, basal $15-2 \% 5$ of siphunculi pale; hind tarsomere I with middle seta $2 / 5-1.0$ times length of other two setae.

Types: Holotype in the I. S. Xational Musenm. Data on the slide

she first measurement is that of the holotype; measurements in parentheses indieate mange in siperinems studied. All measurements are in millimeters. 
"69-65, Phaseolus adenanthus, Picturaphis puertoricensis Smith n. sp. El Yunque, Puerto Rico, East Peak Road, at gate, March 13, 1969 S-M-W." There are three nymphs and one mature aptera on this slide. The mature aptera, No. 1, is the holotype. Paratypes in the following collections: Agricultural Experiment Station of the Universtiy of Puerto Rico; North Carolina State University at Raleigh; British Museum, London, England: H. L. G. Stroyan, Harpenden, England; D. Hille Ris Lambers, Netherlands; and mine.

Type locality: El Yunque, Puerto Rico, at the gate leading to the East. Peak Road.

Collections: On Phaseolus adenanthus, El Yunque, Puerto Rico. 69-65 (Type series), March 13, 1969. C. F. Smith, L. F. Martorell, and R. Woodbury. Twelve slides bearing 1 or more mature aptera and 5 slides with only nymphs. 69-12 same location as 69-65, March 7, 1969. C. F. Smith, C. K. Smith, L. F. Martorell, and R. Woodbury collectors.

\section{SUMMARY}

Picturaphis puertoricensis n. sp. is described and keys are given to separate the species in the genus Picturaphis and closely related genera.

\section{RESUMEN}

Se describe una nueva especie de áfido, Picturaphis puertoricensis n. sp., y se dan claves para separar las especies del género Picturaphis y los géneros más relacionados.

\section{LITERATURE CITED}

1. Blanchard, E. E., Aphid notes. Part III. Argentine species of the subtribes Penlalonia and Aphidina, Physis 6: 43-58, figs. 15-20, 1922.

2. Coquerel, C., Note sur quelques insectes de Madagascar et de Bourbon, Ann. Soc. Entomol. France 7(3): 239-60, PI. 6, 1859.

3. Dnvis, J. J., Two new genera and species of Aphididae, Ann. Entomol. Soc. Amer. 2: 196-200, PI. XXVII, 1909.

4. Moriera, C., Pulgoes do Brasil, Min. Agr., Ind. ('om. Inst. Biol. Def. Agr. 2: 1-34, illus., 11025.

5. Patch, E. M., The Desmodium aphid, Mirroparsus variabilis 11. sp., Entomol. News 20: 337-41, Pls. XVIII-XIX, 1909.

6. Smith, C. F. and Heie, O. E., Megouroparsus, new gemus, related to Microparsus Patch and Megoura Buckton (Homoptera: Aphidae), Ann. Enlomol. Sor . I mer. 56: 401-06; figs. 1-3, 1963.

7. Smith, C. F., Martorell, I. F., and Pérez-liscolar M. E., Aphididac of P'uerto lico, Univ. P. R. Agr. Exp. Sita. Tech. Pap. 37, 1-121, figs. 1-48, 1963. 